\title{
WATER Resources Management: Methodological Proposal For ReAdaPtation OF Hydrological Monitoring of SÃo JoÃo River BASIN, RIO DE JANEIRO STATE (BRAZIL)
}

\author{
Marcelo Wangler de Avila ${ }^{1 *}$, Caroline Domingos de Araújo Silva ${ }^{2}$ and Mônica Galeano de Aquino Massera da \\ HORA $^{1}$
}

1 Universidade Federal Fluminense, Avenida Milton Tavares de Souza, Niterói - RJ, CEP 24210-346, Brazil.

2 Universidade Estácio de Sá, Av. Dom Helder Câmara, 5080, Rio de Janeiro, RJ, CEP 20771-004, Brazil.

*Corresponding Author, mwavila@hotmail.com

Received on 30 November 2017

Received in revised form on 26 February 2018

Accepted on 28 February 2018

Editor: Marcelo dos Santos Salomão, Universidade do Estado do Rio de Janeiro, Brazil

\section{Abstract}

The classic definition of the term Hydrometry refers to the study dedicated to the collection and analysis of hydrological variables. The main objective of hydrological studies is to subsidize projects involving water resources, focusing on their use, such as non-water supply, power generation, irrigation, waterways, effluent dilution, sports and tourism. Thus, in order to perform a successful network planning considering multiple demands and to follow different types of occurrence in a given river basin, it is important to design the hydrological monitoring based on all the actions resulting therefrom, on the physiographic characteristics of the basin under study and on the developed activities. In addition, hydrological monitoring should produce accurate information and continuous operation. Therefore, the present study aims to compile guidelines recommended by the National Water Agency, the Brazilian agency responsible for the implementation of the National Water Resources
Citation:

Avila, M.W., Silva, C.D.A., Hora, M.G.A.M., 2018. Water resources management: methodological proposal for readaptation of hydrological monitoring of São João River Basin, Rio de Janeiro State (Brazil). Journal of Sedimentary Environments, 3 (1): 12-18.

Policy and the National Water Resources Management System. This study also aims to develop a proposal for the planning of the basin's hydrological network of São João River, located in the mesoregion of coastal plains of Rio de Janeiro State. With new technologies support, it focuses on the monitoring of sediment transport, which is fundamental in the decision making regarding future actions of environmental recovery in the basin. Utilizing detailed information, it was possible to verify insufficient monitoring in the basin and to produce a set of recommendations for water resources management based on hydrological monitoring.

Keywords: Hydrological Monitoring. Water Resources Management. Sediments. Hydrographic Basin. Hydrometry. 


\section{Introduction}

Of the total volume of water available on Earth, only $2.5 \%$ correspond to fresh water. Of this percentage, $0.27 \%$ is contained in rivers and lakes, the rest being stored in glaciers (Shiklomanov, 1997). Regarding the better use of fresh water, hydrological studies are necessary to support several kinds of projects aiming for instance to provide water supply, power generation, irrigation, waterway construction, effluent dilution, and dam and reservoir construction.

Hydrological studies are carried out based on water resources governmental plans, strategic environmental assessments, environmental impact studies, river basin plans, projects related to river basin transposition, recovery and protection of springs and riparian forests, and other control and inspection actions aimed at protecting, in quantitative and qualitative aspects, of this scarce and vital survival of mankind (Calijuri and Cunha, 2013). Thus, for a network planning to be successful in multiple demands, it is important to design its monitoring based on all of its consequent actions, that is, considering its physiographic (geomorphological and geological) characteristics and developed activities.

A hydrological monitoring network consists of several points of observation and information collection in a given basin. Those points of observation are called stations. According to Santos et al. (2001), in each type of station, the variables to be measured are defined. Examples of those stations are: limnimetric, which corresponds to the place where water level data are collected; pluviometric, which records precipitation data; fluviometric, where measurements of water quality, solid discharge and flow are carried out; evaporimetric and climatological, where data of temperature, wind velocity and direction, humidity and radiation are recorded.

According to Cabral (2005), the deposition of sediments is the most recurrent problem in reservoirs, causing a decrease in their storage capacity. Cabral (2005) points out that the increase of the solid discharge is generated by precipitation, which ends up transporting those sediments through the fluvial channel and exposure of the soil originated due to the vegetation removal. The sediment transport affects the quality of water for human consumption and for other purposes as it acts as a pollutant and, at the same time, as a catalyst, carrier and fixing agent of other pollutants (Marcelino, 2009).

According to Santos et. al. (2001), the physical and hydrological characteristics are not the same for all the basins and it is not possible to standardize planning networks of hydrological monitoring, but some instructions can be considered as guidelines. The World Meteorological Organization (WMO, 2008) adopted baseline values for the density of pluviometric stations in a river basin. Those values consider the physiographic characteristics of the basin of interest, besides taking into account the conditions of access to the stations. (Table 1).

In relation to the density of fluviometric stations, the WMO (2008) also started to adopt reference values (Table 2), defining a minimum of stations to constitute its monitoring network in each country.

The expansion of agricultural activities and the intense alteration of the land use in basins present a great challenge to the quantification of their degradation. The local climate and topography, associated to the anthropic actions developed in a basin, affect the amount of eroded material (Walling, 1983).
According to Carvalho et al. (2000), another activity that provides increased sediment yield in a basin is mineral extraction.

Tab. 1. Minimum recommended density of pluviometric stations according to the physiographic units. Source: WMO, 2008.

\begin{tabular}{|l|c|c|}
\multicolumn{1}{|c}{$\begin{array}{c}\text { Geographic } \\
\text { Characteristics }\end{array}$} & \multicolumn{2}{c|}{$\begin{array}{c}\text { Minimum Density of Stations } \\
\text { (Area in } \mathrm{km}^{2} / \text { station) }\end{array}$} \\
\cline { 2 - 3 } & No recorder & With recorder \\
\hline Coastal areas & 900 & $\mathbf{9 0 0 0}$ \\
\hline Mountainous areas & 250 & $\mathbf{2 5 0 0}$ \\
\hline Plains and interiors & 575 & $\mathbf{5 7 5 0}$ \\
\hline Steep/rippled areas & 575 & $\mathbf{5 7 5 0}$ \\
\hline Small islands & 25 & $\mathbf{2 5 0}$ \\
\hline Urban areas & - & $\mathbf{1 0 - 2 0}$ \\
\hline Polar and arid zones & $\mathbf{1 0 , 0 0 0}$ & $\mathbf{1 0 0 , 0 0 0}$ \\
\hline
\end{tabular}

Tab. 2. Minimum recommended density of fluviometric stations with limnimetric measurements, with liquid discharge, sediment and water quality. Source: WMO, 2008.

\begin{tabular}{|c|c|c|c|}
\hline \multirow{2}{*}{$\begin{array}{c}\text { Physiographic } \\
\text { Units }\end{array}$} & \multicolumn{3}{|c|}{$\begin{array}{l}\text { Minimum Density of Stations } \\
\text { (Area in } \mathrm{km}^{2} / \text { Station) }\end{array}$} \\
\hline & $\begin{array}{l}\text { Liquid } \\
\text { discharge }\end{array}$ & Sediments & $\begin{array}{l}\text { Water } \\
\text { quality }\end{array}$ \\
\hline Coastal areas & 2,750 & 18,300 & 55,000 \\
\hline Mountainous areas & 1,000 & 6,700 & 20,000 \\
\hline $\begin{array}{l}\text { Plains and } \\
\text { interiors }\end{array}$ & 1,875 & 12,500 & 37,500 \\
\hline $\begin{array}{l}\text { Steep/rippled } \\
\text { areas }\end{array}$ & 1,875 & 12,500 & 47,500 \\
\hline Urban areas & 300 & 2,000 & 6,000 \\
\hline $\begin{array}{l}\text { Polar and arid } \\
\text { zones }\end{array}$ & 20,000 & 200,000 & 200,000 \\
\hline
\end{tabular}

In this way, sediments monitoring becomes a fundamental factor in a decision on the recovery actions of a river basin. For the network planning, the number of sedimentometric stations should correspond to $15 \%$ of the number of fluviometric stations and positioned at the beginning of the average section of the water bodies in the basin (Carvalho and Hora, 2014).

The objective of the present study is to present a proposal for the planning of a hydrological network, taking as reference the São João River Basin (SJRB), located in the mesoregion of the lowlying coastal region of the Rio de Janeiro State (Figure 1), which may be a model for other basins with similar characteristics.

\subsection{Study Area}

The São João River basin (SJRB) covers partially or totally 8 municipalities (Table 3 ) and about 100,000 inhabitants $(25 \%$ of the total population of those municipalities) use the basin water. 


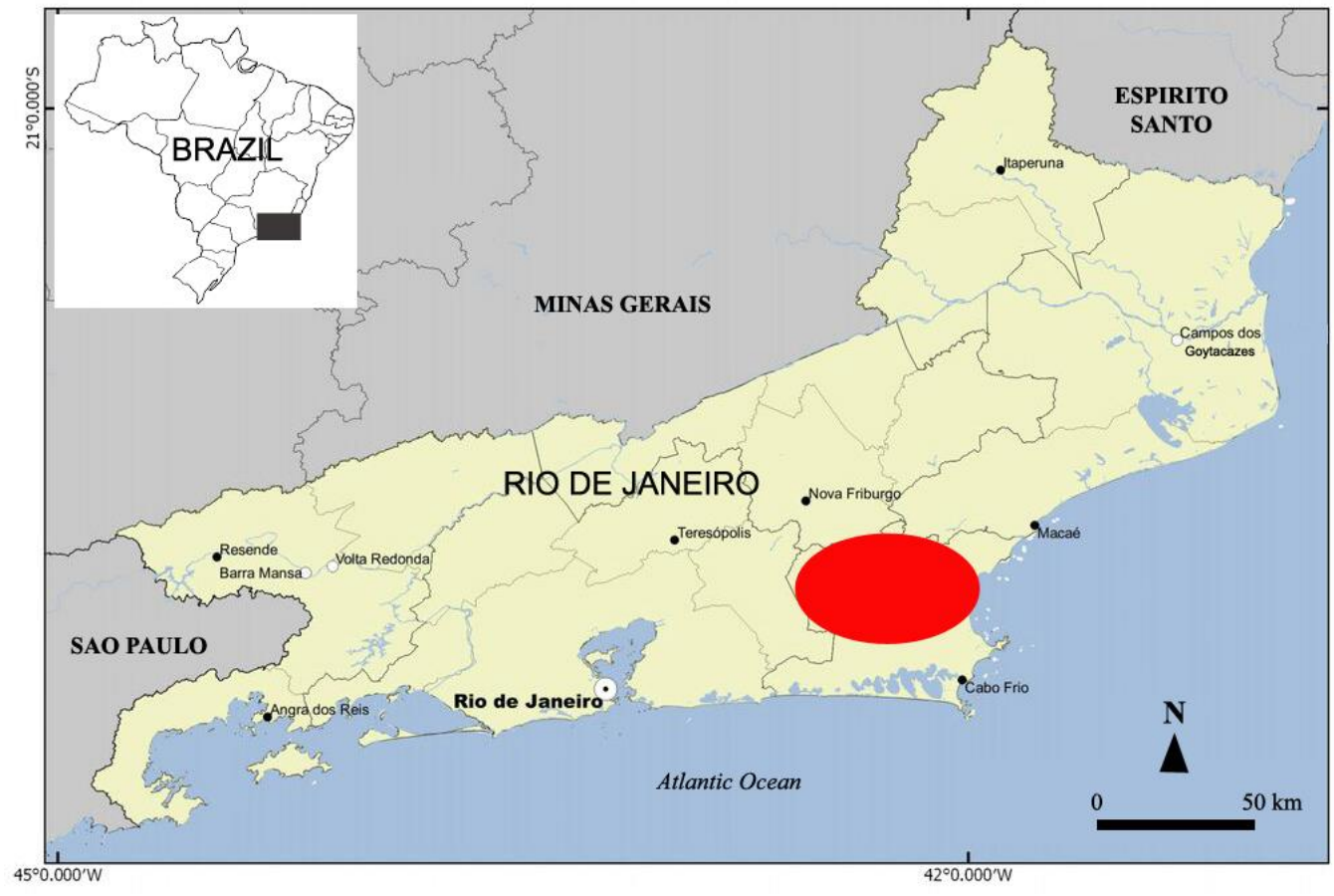

Fig. 1. Location (in red) of the São João River Basin.

According to Primo and Pereira (2005), São João River, the main water body of the basin with the same name, can be divided into three sections:

a) Upper course: this extends for $5 \mathrm{~km}$, descending from an altitude of $800 \mathrm{~m}$ to $200 \mathrm{~m}$ in the first $2 \mathrm{~km}$, with clear waters, but with stones, sand and small backwaters. The tributaries of the São João River valley have wide plains, but the areas where they meet are small. Regarding the forests, they encompass the upper part of the river;

b) Middle Course: this extends for more than $50 \mathrm{~km}$ until the Juturnaíba Dam, running between mountains to the north and a plateau to the south. In this section, the river is at an altitude of $60 \mathrm{~m}$. With a sinuous and slightly rectilinear path, it has a $4 \mathrm{~m}$ wide channel, sandy riverbed, with few stones, containing only pasture on its banks. The banks are high and eroded. The main channel widens starting the straight sections of the São João River, crossing hills with rounded tops and altitudes below 100 meters. The rectified riverbed of the São João River is from 5 to 6 meters wide, shallow and rectangular, high and steep ravines and with clear signs of lateral erosion, without protective woods. Damage caused by sand extraction after rectification works allowed the observation of craters on the margins of the river;

c) Lower Course: downstream of the Juturnaíba Dam, the lower course of the São João River begins, which has its natural bed stretching for $65 \mathrm{~km}$ to the mouth. However, with the artificial canals constructed in the 1970s and 1980s, the waters began to cover $38.5 \mathrm{~km}, 25 \mathrm{~km}$ in a straight channel and $13.5 \mathrm{~km}$ in a natural riverbed. On its final extremity, the channel is connected to ditches that collect waters from tributaries of the São João River.

The São João River Basin (SJRB) is bounded at north by Serra do Mar, with mountains whose altitudes range from 500 to over $1400 \mathrm{~m}$, with a culminating point at $1719 \mathrm{~m}$. The construction of the Juturnaíba Dam submerged about $13 \mathrm{~km}$ from the riverbed, and the movement and deposition of sediments gave rise to a delta. This dam was constructed with the objective of accumulating more water to guarantee the domestic and industrial supply in the municipalities of this region; to control the floods in the São João River basin area, in the stretch downstream of the dam; and ensure water for irrigation of 31,800 ha of agricultural land.

The region has significant climatic diversity, varying from the tropical climate to semi-arid, with great rainfall distribution, which displays spatial and temporal variation. Combined actions of changes of air masses on the area occur throughout the year (Primo and Pereira, 2005). During summer, Continental Equatorial air mass predominates, and during the rest of the year Atlantic Tropical air mass prevails. Polar Atlantic Fronts frequently pass through the region, especially during spring (Primo and Volker, 2003).

The amount of rainfall varies from $1,000 \mathrm{~mm} /$ year to 2,500 $\mathrm{mm} /$ year (Primo and Volker, 2003). Precipitations are higher in the upper portions of the Serra do Mar mountain range and lower in the coastal plains region.

The Atlantic Tropical air mass suffers interference from the Atlantic Polar Fronts, which promote instability and contribute to the warm humid tropical climate in the basin (Primo and Volker, 2003). The Polar Fronts are largely responsible for the annual rainfall peaks, with concentrations between October and March (75\% of the annual total rainfall), with June and July being the driest months (Quintela and Cunha, 1990).

According to data from the Brazilian Institute of Environment and Renewable Natural Resources (IBAMA,1999), in the period prior to the construction of the Juturnaíba dam, there was an important fishing activity in the basin, predominantly catching catfish, mullet, sea bass and shrimp. Bizerril and Primo (2001), in a study about fish from the interior of the Rio de Janeiro State, concluded that the São João River still comprises an ecosystem 
with high biodiversity. However, Mendonça (2004) observed significant reduction of the original fish fauna in the Juturnaíba dam due to the adjustments undergone by the rivers and to the construction of the dam.

Concerning geological aspects, two units predominate: Região dos Lagos Complex and Paraíba do Sul Complex (CPRM, 2014). Fluvio-lagoon deposits of the Quaternary age are present (CPRM, 2000). The lithotypes are distributed in different portions of the SJRB. In the high-stretch section of the basin, garnet-biotitesillimanite quartz-feldspathic gneiss occurs interspersed with calcsilicate gneiss and quartzite, from Região dos Lagos Complex and Proterozoic age (Fonseca, 1989). Type S granite (Desengano Suite, Neoproterozoic) emerges near the source of the São João River and presents garnet-muscovite-biotite, coarse granulation, and granoblastic and porphyritic textures (Rosier, 1957). Tingui Gneiss occurs to the southwest of the basin and corresponds to banded orthogenesis, with thick granulation, with porphyritic and augen textures, and interspersed with deformed gabbro and diorite (Ferrari et al., 1982). Cretaceous/Tertiary alkaline rocks are represented by Morro dos Gatos Alkaline Massif (Motoki et al., 2012).

In the middle course, hornblende-biotite orthogenesis, granodioritic to tonalitic, with intense foliation, predominates. This lithotype is also observed in the lower course, but associated with quaternary deposits. Those deposits correspond to marine and/or lagoon paleoenvironments, colluvio-alluvionar and fluvial lagoons. The first one exhibits quartz sand, with fine to medium granulometry, covered with windy sand. The colluvium-alluvial deposits are formed by white-colored quartz sand, with fine to medium granulometry, covered by aeolian sand. Gravel, sand and sludge from gravitational processes are also observed. The fluviallagoon deposits have sand and mud superposed to sediments of lagoon character (mud). In the lower course, there is the Morro de São João Alkaline Complex, Cretaceous/Tertiary age, constituted by syenite and nepheline syenite (CPRM, 2000).

Tab. 3. Population of municipalities of the SJRB. Source: IBGE, Census 2010

\begin{tabular}{|l|c|}
\multicolumn{1}{|c|}{ City } & Population \\
\hline Cabo Frio & 140,269 \\
\hline Araruama & 76,872 \\
\hline São Pedro da Aldeia & 88,013 \\
\hline Casemiro de Abreu & 35,347 \\
\hline Rio Bonito & 55,551 \\
\hline Silva Jardim & 21,349 \\
\hline Rio das Ostras & 105,676 \\
\hline Cachoeiras de Macacu & 54,273 \\
\hline Total & $\mathbf{5 7 7 , 3 5 0}$ \\
\hline
\end{tabular}

\section{Materials and Methods}

In order to gather the necessary information to plan a hydrological network of the SJRB, the following steps were performed:

\subsection{Recognition of the main urbanized occupations}

The bibliographical survey and visits to the basin area allowed to identify the main public and private ventures in the São João
River Basin, especially dams, and drainage channels, pipelines, highways and back roads, railways, high-voltage transmission lines, basic sanitation infrastructure implemented; agricultural and forestry companies; rural settlements; mineral exploration; districts and industrial complexes, offshore oil exploration activities and protected areas.

Planimetric (including hydrography) and altimetric cartographic data were also investigated and collected, which allowed to design and guide the installation of quantitative control stations (rainfall, level, flow) in the sub-basins.

\subsection{Definition of bydrological variables}

\subsubsection{Pluviometry}

According to Tucci (1997), pluviometry may be denominated as the height of rain that covers a certain region, considering that this water slide does not infiltrate nor evaporate. Its duration corresponds to the time in which the rain falls and its intensity may be calculated from its height divided by the duration $(\mathrm{mm} /$ hour or $\mathrm{mm} / \mathrm{min}$ ). The method of measuring pluviometry is by the use of equipment called pluviometers (rain gauges). As a way of obtaining short-term events and determining the rainfall intensity, equipment with continuous recording is utilized (Santos et al., 2001).

\subsubsection{Limnimetry}

Limnimetry refers to the variation of the river level over time, being measured by means of a ruler or an automatic instrument, in centimeters (Jaccon, 1989). The automatic measurement of water levels is carried out by limnimeters, instruments that allow the continuous storage of the information (Boiten, 2008).

\subsubsection{Liquid discharge}

This is expressed by volume per time, a unit that represents water volume passing through a cross section of the river (Santos et al., 2001). The main flow measurement equipment currently used is hydrometric windmills and acoustic meters. According to ANA (2014), the hydrometric reel allows a better knowledge of the velocity throughout the section and, together with the hydrometric winch, defines the average velocity obtained in each vertical section (Santos et al., 2001). The sum of these flows corresponds to the total flow of that cross section per second (ANA, 2014). Expedited data were used (ANA, 2014).

\subsubsection{Solid discharge}

This corresponds to the concentration of suspended sediments, both in the flow and at the bottom of the drainage (Carvalho and Hora, 2014). The used equipment was an integration suspension sampler, with which the cross section was divided by equivalent discharge values. Expedited data were used (ANA, 2014).

\subsection{Integration of information in a georeferenced environment and planning of the SJRB bydrological network.}

The obtained information was analyzed and inserted in a georeferenced environment, aiming at supporting the planning of the hydrographic network of the SJRB. Its products corresponded to the identification of the current scenario of the existing 
pluviometric stations, of the current fluviometric network, of the geological characteristics and of the proposal of the new hydrographic monitoring network.

\section{Results and discussion}

The São João River hydrographic basin serves 532,408 inhabitants (SNIS, 2015), being characterized by an agricultural occupation formed by irrigated crops both upstream and downstream of the dam, especially rice, citrus and sugar cane. The mechanized extraction of sand in riverbeds is carried out by the dredging of sediments by suction pumps installed on barges or floats on drums, causing:

- macroturbulence in drainage, which changes the flow velocity;

- deepening the river bed;

- resuspension of fine sediments;

- disfigurement of the drainage channel;

- creation of lateral coves in the river channel, which affects the natural habitat of local aquatic species due to increased turbidity.

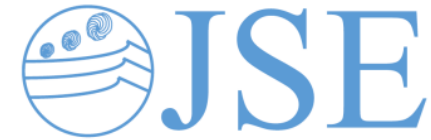

RESEARCH PAPER

In the course of São João River, recent deposits that correspond to marine and/or lagoonal paleoenvironments, colluvio-alluvionar and fluvial lagoons can be observed. The marine and/or lagoonal paleoenvironments exhibits quartz sand, fine to medium granulometry, covered with windy sand. The colluvium-alluvial deposits have white-colored quartz sand, with fine to medium granulometry, covered by aeolian sand.

In order to determine the hydrological monitoring situation in the SJRB, a diagnosis of the existing network and its current conditions was elaborated. The bibliographic research (ANA, 2017) provided the identification and location of the two pluviometric stations for quantitative monitoring in the basin (Figure 2).

In order to compare the number of stations in the SJRB with those proposed by the WMO (2008) for plains and interiors, the density of the pluviometric stations was calculated. In the SJRB, there are stations for the total area of $2,096 \mathrm{~km}^{2}$, resulting in an area of $698.67 \mathrm{~km}^{2}$ per existing station. In this way, a new station would be required, especially in the riverhead, where the rain variability is more intense.

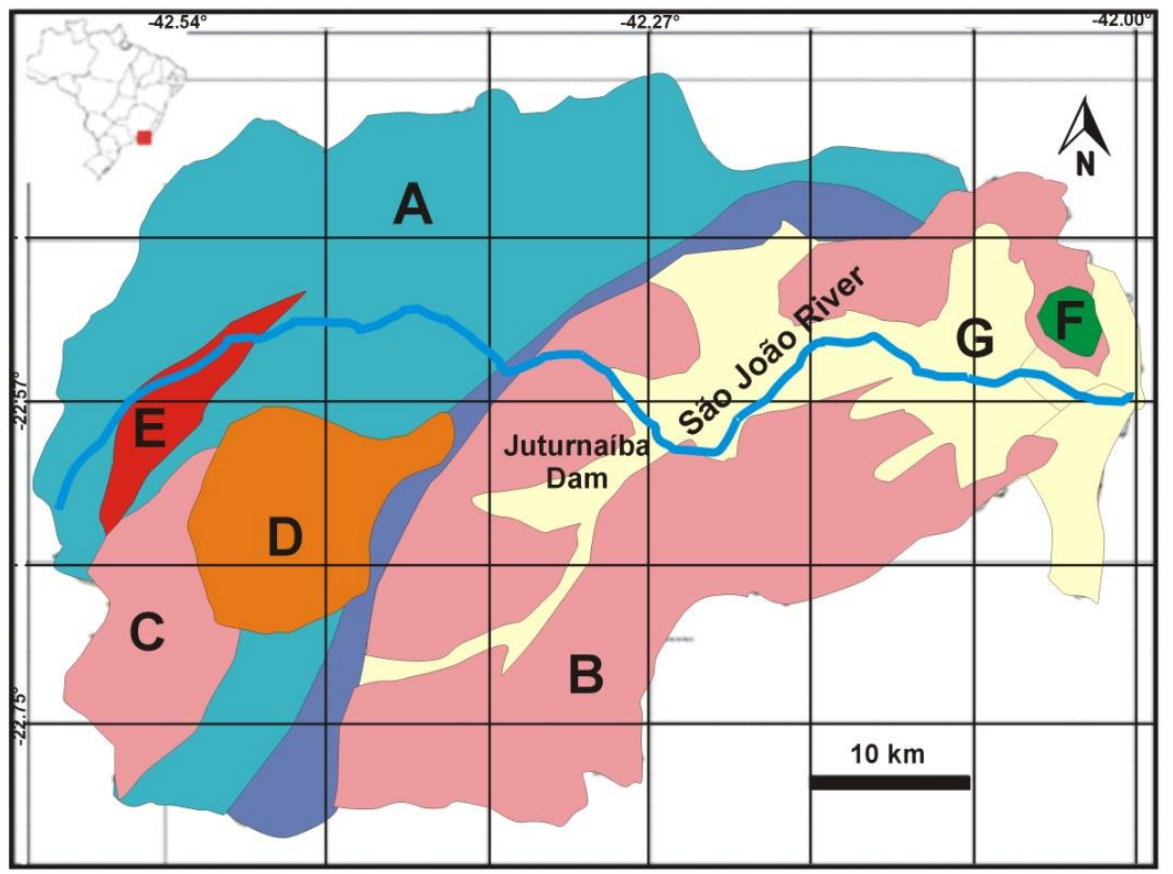

Fig. 2. Simplified geological map of SJRB. Legend: A - Búzios Complex; B - Região dos Lagos Complex; C - Tingui gneiss; D - Postectonic granitoid; E - Desengano Suite; F - Morro de São João alcaline complex; G - Quaternary deposits (modified from CPRM, 2014).

Regarding fluviometric monitoring, Figure 3 illustrates the current fluviometric network, with the two stations in operation and one just deactivated. The stations are near Juturnaíba Lake, in the middle to lower part of the basin, and:

- allow the control of the discharge resulting from the main water bodies of the basin;

- allow analysis of solid discharge data and water quality of these main rivers;

- do not allow the identification of upstream water use;

- do not allow to identify causes of possible problems in the water quality of the water bodies of the basin, since there are no stations in the upper part of the basin;

- several sub-basins are not monitored.
The positioning and the strategic importance of the Juturnaíba Reservoir involved the distribution of the proposed control station for the main tributaries of the São João River, in addition to the lease of a limnimetric station in the reservoir, which will assist the controlling of the available volume to local demands. These control stations of the reservoir, together with the projected evaporimetric station, will allow monitoring the water balance of the reservoir and, in this way, providing the control over the water extraction of in the place. The consequence will be the possibility of adopting the model as an inspector of the demand flows in the Juturnaíba reservoir.

In this way, the proposal for hydrological monitoring in the São João River Basin includes a hydrometric network with stations of different types and with very specific characteristics. The 
network designed for this basin is a mixed network, that is, equipped with conventional and automatic stations. Automatic stations were stationed in locations requiring data collection in a short period of time. In this way, the network becomes more agile in obtaining the data and with more feasible cost for its implementation, according to Figure 4.

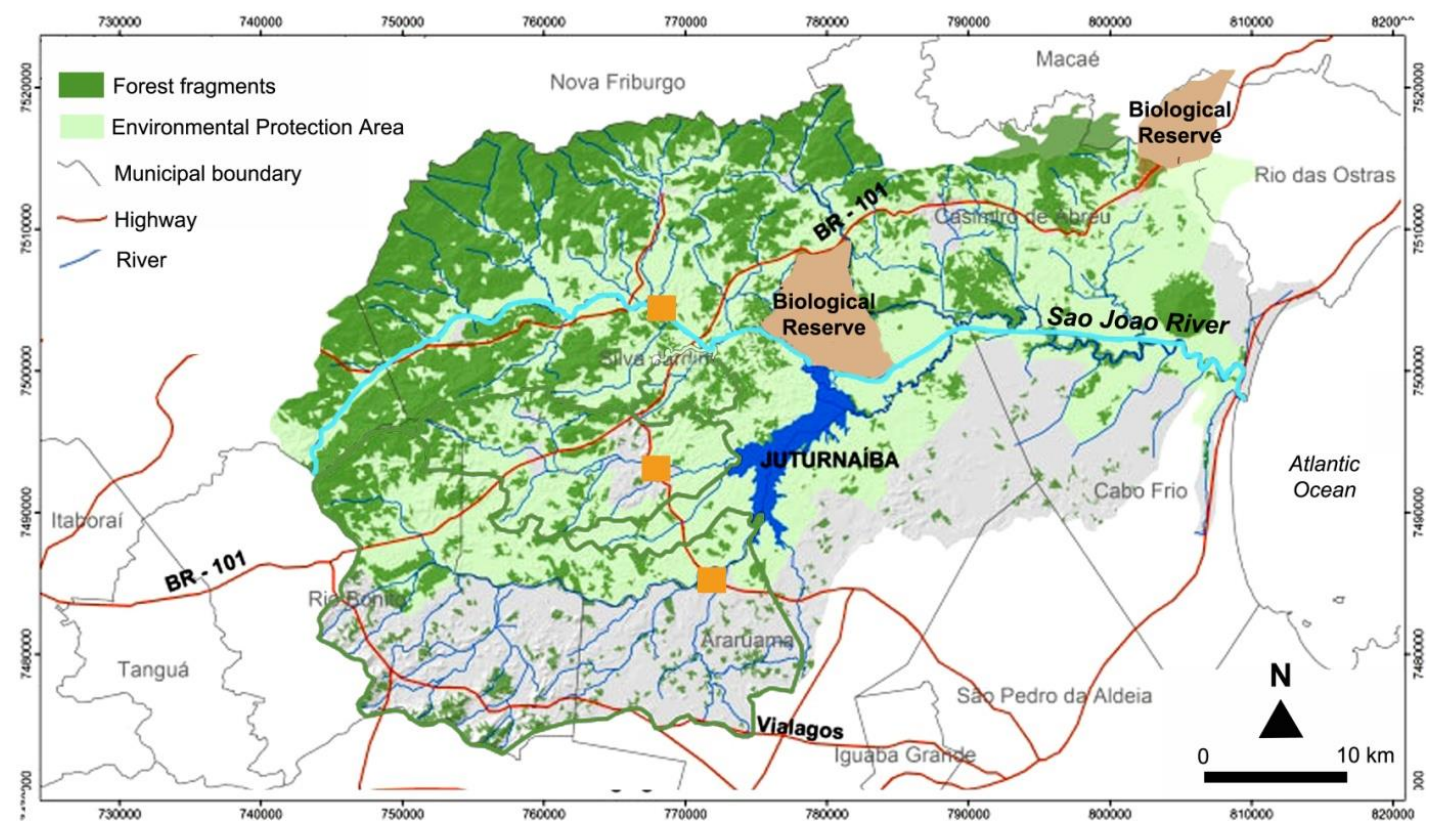

Fig. 3. Current fluviometric network (orange polygons) in the SJRB (Source: ANA, 2017). Modified from Projeto Juturnaíba Viva).

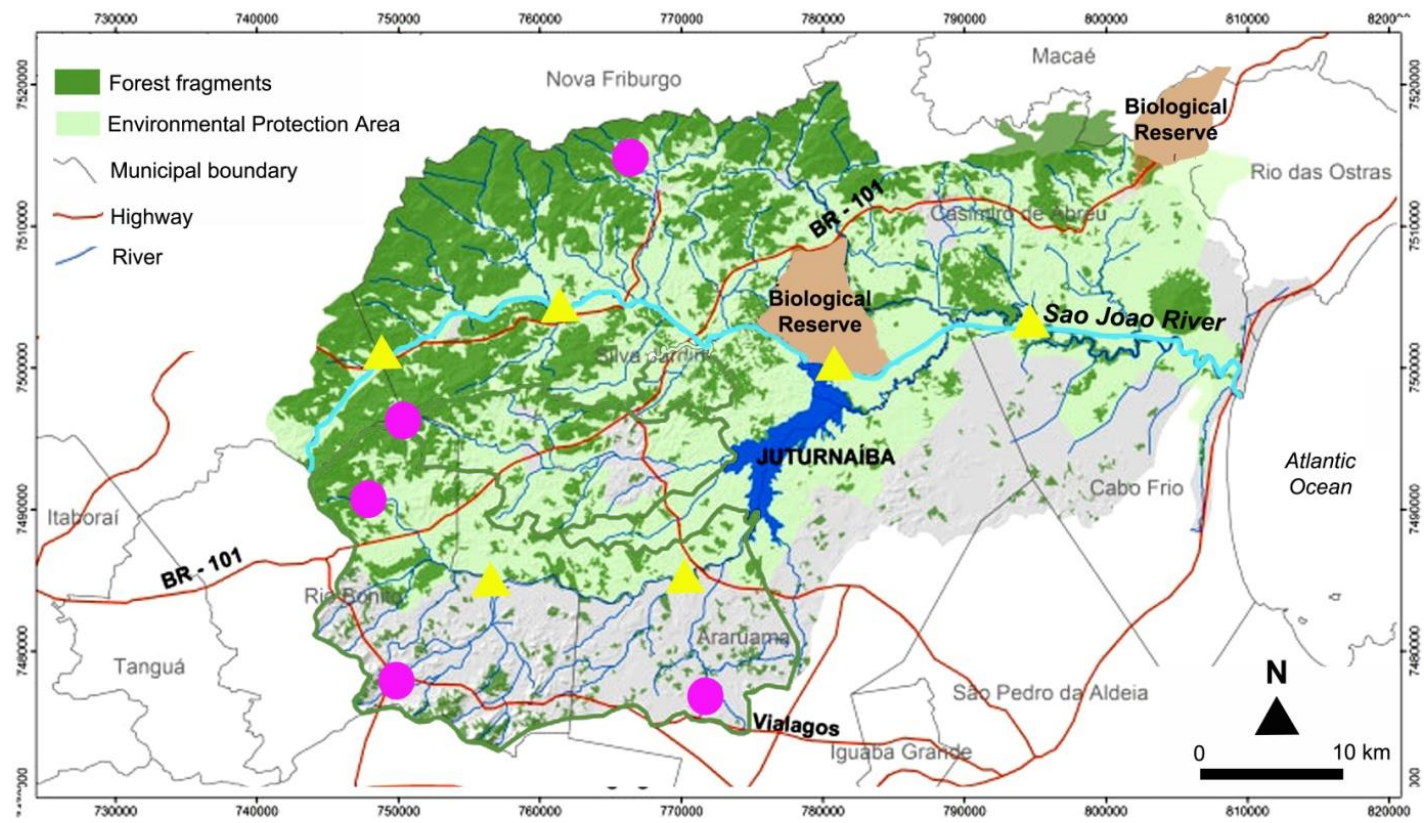

Fig. 4. Fluviometric network designed for SJRB. Pink dots: station with pluviometer. Yellow triangle: fluviometric station. (Modified from Projeto Juturnaiba Viva)

\section{Conclusions}

The hydrometric network in the SJRB is insufficient both from a quantitative point of view (number of stations) and qualitative (their spatial distribution). The necessary hydrometric network must have stations of different types and varied instrumentation. The investment in a hydrometric network should not only occur in its installation, but also in the acquisition of instrumentation for its operation, as well as in the training of technicians who will participate in the proposed monitoring, including the use of geoprocessing and remote sensing techniques in the development of such proposal.

In this way, the SJRB, as many other basins, should prioritize the monitoring of its resources. To achieve the goals, the following items are recommended: 
- the development of a plan for the execution of annual bathymetry of the Juturnaíba reservoir, in order to follow the evolution of sediment accumulation;

- periodic updating of the land use and occupation map of the basin, based on remote sensing and geoprocessing tools, as a way to verify the evolution of the anthropic action and its respective critical points. This map can also support projects to recover river source;

- the training of technicians for operation and maintenance of the network;

- acquisition of the necessary instrumentation for operation of the hydrometric network;

- the development of a supervisory center for the network, in order to allow the acquisition, analysis and storage of the data

- from its operation and that provides technical support to decision-making regarding actions promoted in the basin.

Following the proposal in this work, it will be possible to place the management of the water resources of the São João River Basin in a coherent flow, with the management of the water resources based on hydrological monitoring.

\section{References}

ANA, 2017. Agência Nacional de Águas - ANA, Sistema de Informações Hidrológicas - HIDROWEB, Inventário de Estações Hidrometeorológicas. Available in: http:/ / hidroweb.ana.gov.br/HidroWeb.asp?TocItem=6010. Accessed on: 15 Oct. 2017 at 7:15 p.m.

ANA, 2014. Agência Nacional de Águas - ANA. Medição de Descarga Líquida em Grandes Rios: Manual Técnico, $2^{\mathrm{a}}$ Ed., Brasília.

Bizerril, C.R.S.F., Primo, P.B.S., 2001. Peixes de Águas interiores do Estado do Rio de Janeiro. Rio de Janeiro: FEEMARSEMADS. 417 p.

Boiten, W., 2008. Hydrometry: A comprehensive introduction to the measurement of flow in open channels, Wageningen University, The Netherlands, CRC Press, 247 p.

Cabral, J.B.P., 2005. Estudo do processo de assoreamento em reservatórios. Caminhos da Geografia (online), vol. 6, Uberlândia, MG.

Calijuri, M.C., Cunha, D.G.F., 2013. Engenharia Ambiental: conceitos, tecnologia e gestão. Elsevier, Rio de Janeiro, 789 p.

Carvalho, N.O., Hora, M.A.G.M., 2014. Hidrossedimentometria. In: Poleto, C. (Org.). Sedimentologia Fluvial: Estudos e Técnicas, vol. 1. Porto Alegre: ABRH, p. 10-61.

Carvalho, N.O., Filizola Júnior, N.P., Santos, P.M.C., Lima, J.E.F.W., 2000. Guia de práticas sedimentométricas. Brasília, ANEEL, $154 \mathrm{p}$.

CPRM, 2000. Geomorfologia do Estado do Rio de Janeiro. Brasília.

CPRM, 2014. Mapa geológico e de recursos minerais do Estado do Rio de Janeiro. Brasília.

Ferrari, A.L., Brenner, T.L., Dalcolmo, M.T., Nunes, H.R.C. 1982. O Precambriano das folhas Itaboraí, Maricá, Saquarema e Baia de Guanabara. In: XXXII Congresso Brasileiro de Geologia, Atas, 1, 103-113.
RESEARCH PAPER

Fonseca, M.J.C., 1989. O Cinturão Ribeira e o Bloco Cabo Frio. In: SBG, Simpósio Geológico do Sudeste, Atas, 1, p.132-133.

IBAMA, 1999 - Instituto Brasileiro do Meio Ambiente e dos Recursos Naturais Renováveis. Recuperação da ictiofauna do complexo de Juturnaíba, Rio de Janeiro, IBAMA, 83 p.

Jaccon, G., Cuddo, K.J., 1989. Curva-chave: análise e traçado: Brasília, Departamento Nacional de Águas e Energia Elétrica. Brasília: DNAEE.

Marcelino, L., 2009. Transporte de sedimentos em suspensão nos rios catarinenses. Centro Tecnológico/Universidade Federal de Santa Catarina, 71p.

Mendonça, H.S., 2004. Caracterização e afinidades da ictiofauna do Reservatório de Juturnaíba, em Silva Jardim, Estado do Rio de Janeiro. MsD Thesis, Museu Nacional/Universidade Federal do Rio de Janeiro, 99 p.

Motoki, A., Geraldes, M.C., Iwanuch, W., Vargas, T., Motoki, K.F., Balmant, A., Ramos, M.N., 2012. Pyroclastic dyke and welded crystal tuff of the Morro dos Gatos alkaline intrusive complex, State of Rio de Janeiro, Brazil. REM-Revista Escola de Minas, 65 (1): 35-45.

Primo, P.B.S., Pereira, L.F.M., 2005. Plano de bacia hidrográfica da Região dos Lagos e do Rio São João. Consórcio Intermunicipal para Gestão das Bacias Hidrográficas da Região dos Lagos, Rio São João e Zona Costeira - CILSJ, Rio de Janeiro - RJ, 156 p.

Primo, P.B., Volker, C.M., 2003. Bacias hidrográficas dos rios São João e das Ostras: águas, terras e conservação ambiental. Rio de Janeiro, Consórcio Intermunicipal, Lagos, São João.

Quintela, M.A., Cunha, S.B., 1990. O regime pluviométrico e o diagnóstico ambiental na área de influência do reservatório de Juturnaíba, RJ. Anuário do Instituto de Geociências. Universidade Federal do Rio de Janeiro, p. 167-182.

Rosier, G.F. 1957. A geologia da Serra do Mar entre os picos da Maria Comprida e do Desengano. DNPM/DGM, Boletim 166 p.

Santos, I., Fill, H.D., Sugai, M.R.B., Buda, H., Kishi, R., Marone, E., Lautert, F.L., 2001. Hidrometria aplicada. Curitiba: LACTEC (Instituto de Tecnologia para o Desenvolvimento Centro Politécnico), 372 p.

Shiklomanov, I.A., 1997. Comprehensive assessment of the freshwater resources of the world: assessment of water resources and water availability in the world. Geneva: WMO, 85 p.

SNIS, 2015. Sistema Nacional de Informações Sobre Saneamento, (SNIS), Sistema de Coleta de Dados de Água e Esgoto. Available in http://www.snis.gov.br/PaginaCarrega.php? EWRErterterTERTer=86, accessed 15/10/2017, at 22:25h.

Tucci, C.E.M., 1997. Hidrologia: ciência e aplicação. Porto Alegre, Editora da Universidade, 943p.

Walling, D.E., 1983. The sediment delivery problem. Journal of Hydrology 65, 209-237.

WMO, 2008. World Meteorological Organization. Guide to hydrological practices, data acquisition and processing, analysis, forecasting and other applications. Fifth edition, No 168, Genebra - Switzerland, Cap. 20, 293 p. 